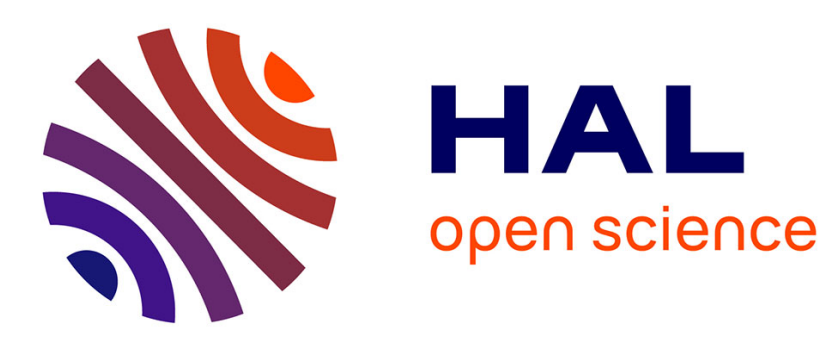

\title{
The shapes of dikes: Evidence for the influence of cooling and inelastic deformation
}

Katherine A. Daniels, Janine Kavanagh, Thierry Menand, R.S.J. Sparks

\section{To cite this version:}

Katherine A. Daniels, Janine Kavanagh, Thierry Menand, R.S.J. Sparks. The shapes of dikes: Evidence for the influence of cooling and inelastic deformation. Geological Society of America Bulletin, 2012, 124 (7/8), pp.1102-1112. 10.1130/B30537.1 . hal-00720251

\section{HAL Id: hal-00720251 \\ https://hal.science/hal-00720251}

Submitted on 16 Apr 2015

HAL is a multi-disciplinary open access archive for the deposit and dissemination of scientific research documents, whether they are published or not. The documents may come from teaching and research institutions in France or abroad, or from public or private research centers.
L'archive ouverte pluridisciplinaire HAL, est destinée au dépôt et à la diffusion de documents scientifiques de niveau recherche, publiés ou non, émanant des établissements d'enseignement et de recherche français ou étrangers, des laboratoires publics ou privés. 
1 The shapes of dikes: evidence for the influence of cooling and inelastic deformation.

2 Katherine A. Daniels ${ }^{1}$, Janine L. Kavanagh ${ }^{2}$, Thierry Menand $d^{3,4,5}$ and R. Stephen J. Sparks ${ }^{1}$.

$3{ }^{1}$ School of Earth Sciences, University of Bristol, Wills Memorial Building, Queen's Road, 4 Bristol, BS8 1RJ, U.K.

$5{ }^{2}$ School of Geosciences, Monash University, Clayton Campus, Wellington Road, Clayton, 6 Victoria, 3800, Australia.

$7{ }^{3}$ Clermont Université, Université Blaise Pascal, Laboratoire Magmas et Volcans, BP 10448, F863000 Clermont-Ferrand, France.

$9 \quad{ }^{4}$ CNRS, UMR 6524, LMV, F-63038 Clermont-Ferrand, France.

$10{ }^{5}$ IRD, R 163, LMV, F-63038 Clermont-Ferrand, France.

\section{Abstract}

13 We document the shape of dikes from well exposed field locations in the Isle of Rum, Scotland, 14 and Helam Mine, South Africa. The basaltic Rum dikes crop out on a smaller scale than the 15 Helam kimberlite dikes and have a smaller length to thickness ratio ( 100:1 Isle of Rum, $16 \sim 1000: 1$ Helam Mine). We compare dike thickness field measurements with the geometry 17 predicted by elastic theory, finding best-fit models to estimate magma overpressure and regional 18 stress gradients at the time of dike emplacement. Most of the dike shapes fit poorly with elastic 19 theory, being too thick at the dike ends and too narrow in the middle. Our calculated 20 overpressures and stress gradients are much larger than independent estimates based on rock 21 strength. Dike shape can be explained by a combination of host rock inelastic deformation and 22 magma chilling at the dike's tapering edges preventing its closure as magma pressure declines 
23 during emplacement. The permanent wedging of the dike edges due to chilling has implications

24 for crustal magma transport and strain response in the crust due to dike emplacement.

\section{$26 \quad$ 1. Introduction}

27 Dikes are the end result of the flow of pressurised magma through fractures, recording a 28 fundamental mechanism of magma transport through the crust. Dike shapes reflect the 29 integration of complex emplacement and eruption processes, where host-rock deformation, 30 magma viscosity, magma pressure variations, stress distribution and heat transfer all play a role.

31 Many theoretical and experimental studies of dike emplacement emphasize elastic deformation 32 by pressurised magma-filled fractures (e.g. Gudmundsson 1983, Lister and Kerr 1991, Kerr and 33 Lister 1995, Rubin 1995, Menand and Tait 2001, Menand and Tait 2002, Ray et al. 2007, 34 Menand et al. 2010).

36 The shape of a preserved solidified dike can be used to calculate the pressure in the crack at the 37 time of solidification, assuming that the shape reflects a simple elastic deformation control with 38 fixed overpressure. Previous studies of dike shape have involved the measurement of dike thicknesses in the field and the observed dike cross-sectional profiles have been compared with elastic models in order to estimate the driving pressures and stress gradients at the time of emplacement (Pollard and Muller 1976, Delaney and Pollard 1981, Rubin and Pollard 1987,

42 Poland et al. 2008, Geshi et al. 2010, Kavanagh and Sparks, 2011). Others have used theoretical 43 numerical models to interpret the evolution of dike thickness. Buck et al. (2006) found that the 44 stopping pressure of a dike (the point where the difference between the magma pressure and the tectonic stress (the driving pressure) at the dike tip becomes too small to propagate the dike) is 
46 proportional to its thickness. They also found that the propagation distance is dependent on the

47 initial distribution of tectonic stress and that dike intrusions affect the tectonic stress distribution,

48 therefore affecting the propagation of subsequent dikes. Gudmundsson (2011) suggests that dike

49 arrest is dependent on a number of factors including the size of the process zone (a region of

50 highly fractured host-rock formed ahead of the propagating intrusion (see, for example, White et

51 al., 2011)), in addition to the fracture toughness of both the host-rock itself and the interfaces

52 between rock units. As a consequence, two dikes with the same overpressure could have quite

53 different thicknesses.

54

55 We document the shapes of well exposed examples of basaltic dikes from the Isle of Rum,

56 Scotland, and kimberlite dikes from Helam Mine, South Africa. Firstly we describe the

57 geological settings of the dikes and present detailed dike-thickness datasets. We then summarize

58 the theoretical framework used to assess to what extent elastic deformation can describe dike

59 shape. We find that the shapes of most of the dikes have a poor fit with that expected from elastic

60 theory and propose that the shapes can be explained by including the complicating effects of

61 magma chilling at the dike's tapering edges and host-rock inelastic deformation.

62

63 Our observations have implications for understanding the development of dikes as conduits and

64 for the effects of dikes on transient stresses and crustal strain. Through the permanent wedging

65 open of the crust by chilled dike edges, a dike can act as a potential conduit for longer, increasing

66 the longevity of eruptions. In addition the crustal strains implicit in dike emplacement reflect not

67 only responses to tectonic stress but also magma overpressures preserved at the dike edges by

68 chilling. 


\section{$70 \quad$ 2. Geological settings}

71 Basaltic dikes from the Isle of Rum

72 Situated off the west coast of Scotland, the Isle of Rum represents the eroded remnants of a 73 shallow-level igneous complex emplaced into Torridonian Pre-Cambrian sandstone at 74 approximately 2-3 km depth (e.g. Emeleus 1997, Nichols et al. 2009). Rum's igneous rocks 75 include layered basic and ultrabasic intrusions, granophyres, volcanic rocks ranging from 76 rhyolite to picrite, and hypabyssal intrusions (Emeleus 1997). The focus of this study is a late 77 stage NW- to NNW-striking basaltic dike swarm (Emeleus 1997) dated to $60.53 \pm 0.08 \mathrm{Ma}$

78 (Hamilton et al. 1998). The Isle of Rum and the dike measurement locations are shown in 79 Figures $1 \mathrm{~A}$ and $\mathrm{B}$.

80

81 A dike length and thickness dataset was compiled. The length of each of the dikes selected was 82 measured using a tape measure; only dikes with crack tips exposed at both ends were selected for 83 measurement. The thickness of the dike was then measured at regular intervals. For the majority 84 of the dikes, this was done by hand in the field. For a few of the largest dikes measured, this was 85 done using scaled photographs. All measured thicknesses were then corrected for the dip angle 86 of the dike to give the true thickness. A total of 1068 thickness measurements along the length of 8741 dikes are presented; some of these are thought to be en echelon segments of a single dike; for 88 simplicity we treat each segment individually as if they were separate dikes, referring to them as 89 dikes rather than dike segments. We will address this simplification later on in the Discussion. 90 The Isle of Rum dikes have a thickness:length ratio ranging from 1:11 to 1:449, with an average 91 of 1:56. The measured lengths range between 0.08 and $47.6 \mathrm{~m}$; the measured thicknesses range 
92 between $0.007 \mathrm{~m}$ and $0.62 \mathrm{~m}$ with an average maximum thickness of $0.052 \mathrm{~m}$. For most dikes the

93 thickness measurements are accurate to about $2 \mathrm{~mm}$. The largest dikes have thicknesses that are

94 accurate to within $5 \mathrm{~mm}$, and lengths that are accurate to the nearest $0.05 \mathrm{~m}$. The smallest dikes

95 are likely to be part of a segmented dike, or offshoots from a larger dike, and are not expected to

96 have travelled far. The dikes intruded contact metamorphosed Torridonian Sandstone. Most

97 dikes show pronounced chilled margins of at least a few millimeters (Figure 2A) and many show

98 internal cooling fractures (Figure 2B). Many Rum dikes exhibit crack tip infilling with sediment

99 (Figure 2A) and some show branching. Most dikes cross-cut pre-existing bedding and joints, or

100 are themselves affected by post-emplacement jointing (Figure 2B). Few dikes have joint

101 controlled orientations (Figure 2C) and those affected by a previous joint set were not included

102 in the analysis. Occasional host rock inclusions are seen (Figure 2B).

103

104 The Swartruggens Kimberlite Dike Swarm

105 The Swartruggens Kimberlite Dike Swarm, Helam Mine, South Africa, comprises three dikes; 106 two kimberlites (Main and Changehouse dikes) and a lamprophyre (Muil dike). The dikes 107 intruded at the end of the Jurassic (Allsopp and Barrett, 1975; Phillips, 1991; Gurney and 108 Kirkley 1996), and cut a stratigraphy comprising dolerite, quartzite, shale and andesite lava from 109 the Proterozoic Pretoria Group, central Kaapvaal craton. The estimated magma emplacement 110 depth is 2-3 km (Brown et al. 2007). Mine excavations extend to $750 \mathrm{~m}$ deep and give a three111 dimensional view of the structure of the kimberlite dikes. A unique dataset of 683 dike-thickness 112 measurements from Levels 16-21 of John's dike segment, and 704 dike thickness measurements 113 from Levels 19-22 of Edward's dike segment are presented. The measurements were made by 114 hand using a tape measure by a number of geologists systematically since the mine has been 
115 active. A simplified diagram of the field relationships of these dike segments is shown in Figures $1163 \mathrm{~A}$ and $\mathrm{B}$.

118 The Main dike comprises a series of anastomosing en echelon segments extending $7 \mathrm{~km}$ (Basson 119 and Viola 2003). The dike segments trend approximately east-west with a thickness:length ratio 120 of $\sim 1: 1000$; each segment strikes approximately $1 \mathrm{~km}$ in length with a mean thickness of $0.64 \mathrm{~m}$ 121 (Kavanagh 2010; Kavanagh and Sparks, 2011). The measurements made of dike thickness are 122 accurate to the nearest $0.05 \mathrm{~m}$. The lateral extent of the mined excavation is used as a proxy for 123 the breadth of the dike as this closely follows the dike geometry; the errors associated with this 124 measurement are estimated at less than 10 meters. Breccia zones up to several tens of meters 125 wide occur in the regions between dike segments, where centimeter-sized angular country rock 126 fragments have formed (Brown et al. 2007). These fragments occur as inclusions within the 127 kimberlite. Spheroidally weathered dolerite is associated with breccia zones and centimeter-thick 128 dike-parallel fracture zones that occur in the host rock at the dike margins (Brown et al. 2007). 129 The country rock away from the dike is unbrecciated, lacking closely spaced fracturing and 130 spheroidal weathering.

131 The Swartruggens dikes are not thought to be controlled by pre-existing fractures, having instead 132 created and intruded their own fractures during ascent. The host rock is jointed with no dominant 133 orientation, is brecciated especially near the fracture tips, and there is evidence for stoping 134 (Brown et al. 2007). Chilled margins were not recognized in the Swartruggens dikes; they likely 135 existed but are obscured by post-emplacement serpentenization. Closely-spaced host rock 136 fracturing, predominantly sub-parallel to the dike contact, is pervasive in the vicinity ( 0.1 to $1 \mathrm{~m})$ 137 of the Swartruggens dike margins. 


\section{3. Theoretical framework and comparison with field data}

140 Elasticity theory (e.g. Timoshenko and Goodier 1970, Landau and Lifshitz 1986) describes the

141 two-dimensional shape of a fluid-filled fracture subjected to a stress field in a homogenous and

142 isotropic material (Sneddon 1946, Pollard and Muller 1976):

$u_{y}=\frac{l \sin \theta}{2 G}\left[\left(P_{o}-S_{y o}\right)(1-v)\right]=\frac{l \sin \theta}{2 G}[(\Delta P)(1-v)] \equiv A \sin \theta$

$u_{y}=\frac{l^{2} \sin 2 \theta}{16 G}\left[\left(\nabla P-\nabla S_{y}\right)(1-v)\right] \equiv B \sin 2 \theta$

where $l$ and $u_{y}$ are the crack length and displacement, $\theta$ is the angular position along the slit from the crack centre, $G$ is the elastic shear modulus, $P_{o}$ and $S_{\jmath^{\prime}}$ are the magma pressure and regional stress normal to the crack, $\Delta P$ is the excess magma pressure $P_{o}-S_{y}, v$ is the host rock's Poisson's ratio, $\nabla P$ is the magma pressure gradient along the crack, $\nabla S_{y}$ is the regional normal stress gradient along the crack, and A and B are constants. Model parameter values are given in the caption to Figure 4.

The overall displacement of the margins of the fluid filled crack is the result of a summation of both Equations (1) and (2). Equation (1) gives the displacement due to the application of a

157 uniform internal pressure with no gradient in regional stress, whilst Equation (2) gives the 158 displacement as a result of a linear gradient along the dike length as the difference between the 159 regional stress and magma pressure. Models including a constant driving pressure plus a gradient 160 in driving pressure or regional stress along the dike length will create a dike profile with a 
teardrop shape (Pollard 1987). Asymmetrical dike profiles have been attributed to gradients in magma pressure or regional stress with the magnitude of asymmetry being controlled by the length of fracture, overpressure and effective stress gradient (Pollard and Muller 1976).

We analyze dike-thickness measurements from the two datasets using the method of Pollard and Muller (1976). Equations (1) and (2) were iterated through 10,000 permutations of A and B to estimate the best parameter values that minimize the least squares misfit between the model and the observations. Overpressures and linear stress gradients are estimated from the best-fit models. The estimated values of overpressure and linear stress gradient are then used as a reference for comparison with the field data. These equations have been used to generate a model to fit the shape of an observed solidified magma filled crack. By interpreting the static shape, the assumption has been made that the fluid filled crack had reached a static equilibrium and that flow effects as solidification occurred can be neglected.

\section{The shapes and thicknesses of the dikes}

Figure 4 shows examples of representative dike profiles for Rum and Swartruggens as horizontal cross-sectional slices. It is assumed that the cross-sectional profile of the dikes at each field locality is approximately horizontal. The best fitting elastic model is shown as the solid black line. Overpressures estimated from the models range from 37-1990 MPa, averaging $678 \mathrm{MPa}$ $\left(\mathrm{R}^{2}=0.389-0.997\right.$, average $\left.=0.921\right)$ for Rum, and from $4-40 \mathrm{MPa}\left(\mathrm{R}^{2}=0.50-0.72\right)$ for Swartruggens (Table 1). Estimated regional stress gradients for the Rum dikes estimated from the theory are up to $3 \mathrm{GPa} \mathrm{m}^{-1}$, averaging $622 \mathrm{MPa} \mathrm{m}^{-1}$, and range from $15-87 \mathrm{kPa} \mathrm{m}^{-1}$ for Swartruggens (Table 1). 
183 A comparison of the values of overpressure and stress gradient estimated for the Rum and

184 Swartruggens dikes with values obtained by previous studies are also given in Table 1.

186 The range of $\mathrm{R}^{2}$ values for the best-fit models indicate that many of the dike segments do not fit 187 the elastic model well. In Figure 4 the data have been normalised $\left(L^{*}\right)$ to the overall length of 188 each dike giving the tips at -0.5 and +0.5 . This normalization procedure allows us to compare the 189 dikes of different length scales, and to compare all the data with the elastic model in one 190 diagram.

192 In Figures 5A) to D), all thickness measurements have been referenced to the model fit which is 193 plotted as a horizontal line in the normalised co-ordinates to show departures in dike thickness 194 from the model. Figures 5C) and D) show the same graphs as Figures 5A) and B) but with a 195 larger scale on the y-axis. Negative y-axis values indicate a dike which is thicker than predicted 196 by the model, while positive values show a dike that is thinner than predicted. Frequency 197 histograms of the difference between the modelled thickness and the measured thickness for the 198 Rum and Swartruggens dikes are shown in Figures 5E) and F), respectively. For both localities, 199 the distribution of the data from the central portions of the dikes ( $L^{*}=-0.3$ to 0.3 ; red bars) is 200 positively offset from 0 on the $\mathrm{x}$-axis whilst the distribution of the data from the edge portions of 201 the dikes $\left(L^{*}<-0.3\right.$ and $>0.3$; black bars) is negatively offset from 0 on the $\mathrm{x}$-axis. The mean 202 average difference between the model and the measured data in the central portion is 0.11 for the 203 Rum data, and 0.02 for the Swartruggens data, whilst for the edges the difference is -0.10 for the 204 Rum data and -0.29 for the Swartruggens data. The Rum and Swartruggens dikes both show, 
205 irrespective of goodness of fit, that dikes strongly tend to be thicker than expected by the model 206 at their edges and thinner than expected in their centers.

208 Our data shows dike segments are commonly asymmetrical about their length mid-point. In plan209 view, the Swartruggens dikes and many Rum dikes are skewed so the point of maximum 210 thickness is not at the dike centre (e.g. Figure 4B). We have quantified dike asymmetry $(\delta)$ by 211 comparing the best-fit model centre with the dike's normalized length mid-point: a $\delta$ of 0 is 212 symmetrical and 0.5 is maximum possible asymmetry. For the Rum dikes, $\delta$ ranges from $0-0.47$ 213 (average 0.142, standard deviation (s.d.) 0.110), for the Swartruggens dike John segment $\delta$ 214 ranges from 0.087-0.203 (average 0.154, s.d. 0.054), and from 0.179-0.242 (average 0.205, s.d. 215 0.031) for the Edward segment. The Rum dikes have a broader range of $\delta$ values; some dikes 216 show extreme asymmetry. The Swartruggens dikes are more skewed than the Rum dikes with 217 less variation in $\delta$. We found no correlation between asymmetry and dike size. Neighbouring 218 segments commonly show asymmetry in alternating directions which may be the result of 219 compression as one dike segment influences the next one (e.g. Pollard et al. 1982, Roman and 220 Cashman 2006).

\section{5. Discussion}

223 We first discuss dike segmentation and our simplified analysis, before discussing the two kinds 224 of mismatch we found between the elastic theory and the observations: estimated overpressure 225 and stress gradient values are implausibly high, and dikes are systematically thicker at the edges 226 and thinner in the middle. 
229 Some of the dikes measured on Rum are individual dikes (4) (Figure 6A) whilst others are 230 segments of a larger dike (37) (Figure 6B). The Swartruggens dikes are segments of a larger 231 regional intrusion. Previous workers have treated segmented dikes both as individual intrusions 232 or have modelled the segments together as one intrusion (e.g. Pollard and Muller 1976, Delaney and Pollard 1981, Baer 1991 and Poland et al. 2008). Dike segmentation commonly occurs in response to stress field rotation or propagation at an angle to the principal stress directions, giving a series of en echelon dike fingers, or segments, with systematic step-overs between segments owing to tangential stress on the dike walls (Pollard 1987). Segmentation may also 237 reflect dike propagation through heterogeneous geological media with local deviations of the stress field. The Swartruggens dikes and most of the Rum dikes are better interpreted with the latter explanation as the segments step direction is non-systematic. Segmentation implies a more complicated local stress regime than a static elastic theory based on a fluid filled crack and these complications are not easily qualified. Indeed the correct mathematical treatment of this complex

242 problem requires knowledge of the principal directions, principal stresses and magma overpressure distribution along the fluid-filled crack (Meriaux and Lister, 2002); a priori estimates based solely on dike orientations can lead to significant errors in the principal stress values (Meriaux and Lister, 2002), and thus the quantification of dike segmentation.

247 Additionally, we note some difficulties in treating a dike with several segments as a single dike.

248 Although in some cases this can provide a better fit to the thickness data (e.g. Delaney and 249 Pollard 1981, Poland et al. 2008), especially if the thickness close to the tips is not measured, the quality of the fit inherently depends on the amount of data and their position along each segment. 


$$
u_{s}=\frac{2 \Delta P(1-v)}{\pi G} a(1+s)\left\{\ln \left[\cos \left(\frac{\pi x}{2(1+s)}\right)+\sqrt{\cos ^{2}\left(\frac{\pi x}{2(1+s)}\right)-\cos ^{2}\left(\frac{\pi}{2(1+s)}\right)}\right]-\ln \left[\cos \left(\frac{\pi}{2(1+s)}\right)\right]\right\} .
$$
$v$ is the host-rock Poisson's ratio, $G$ its shear modulus, and the tip-to-tip distance $d$ between adjacent dike segments is normalised to the segment length: $s=d / 2 a$. Figure 7 shows how much the opening of multiple segments differs from that of a single one with the same overpressure.

266 Closer dike segments have greater openings, but even for dike segments separated by 1/1000 of 267 their length this opening is increased only by a factor of less than five (Figure 7B). The segment openings are proportional to their overpressure, and consequently this simplified analysis

270 factor of about five. A more robust analysis would consider the relative positions of observed 271 segments, but this would require a numerical treatment. However, the contribution of segments with larger spacing would be lower, and could offset some of the closest segments. 
274 To investigate further the effect of analyzing dike segments collectively rather than separately, 275 we have compared this analysis with the profile of six en echelon dikes from one locality on the 276 Isle of Rum. The dikes at this particular locality are thought to be a completely exposed 277 segmented dike; at all other localities where the dikes were segmented the complete extent of the 278 dike is less certain. These six dike segments are not truly collinear, however. There is always 279 some separation, as measured normal to one segment, and they also tend to overlap, with both 280 separation and overlap distances varying significantly from a pair of segments to one another.

281 We have thus used the collinear, segmented dyke analysis with a range of tip-to-tip spacing 282 between segments, from $1 \mathrm{~m}$ down to $0.1 \mathrm{~mm}$. As for the previous analysis, equation (3) was 283 iterated through 1000 permutations of $\Delta P$ to estimate the best overpressure value that minimizes 284 the least squares misfit between equation (3) and the measured opening for each segments. The 285 best overpressure estimates range from $73 \mathrm{MPa}$ to $1906 \mathrm{MPa}$ with an averaged estimate of 430 $286 \mathrm{MPa}$. The highest estimate, found for only one of the six segments, is an order of magnitude 287 higher than the other five estimates; adjacent segments belonging to the same dike should have 288 similar overpressures. Neglecting this highest value gives an average overpressure estimate of $289135 \mathrm{MPa}$. Although these values are lower than those estimated with Pollard and Muller's 290 analysis, the best overpressure estimates predicted by the segment analysis are still much higher 291 than values documented in previous studies (Table 1). Figure 8 shows the best-fit profiles for 292 both single-dyke and segmented-dyke analyses for two of the selected segments. Both analyses 293 fail to explain the thick edges displayed by the segments (Figure 8A). Additionally, the segment analysis only deals with constant stress, and so cannot say anything about regional stress gradients nor explain the asymmetrical, teardrop shape displayed by most segments (Figure 8B). 
297 Finally, several of the Rum segments overlap. We are not aware of any analytical solution for

298 estimating overpressures, stress gradients or shape for overlapping segments; this would require 299 numerical computations. Considering a constant overpressure, Pollard et al. (1982) showed that 300 overlapping segmented dikes would be fatter than a single one. So by considering each segment 301 as an individual dike, one would overestimate its overpressure. This overestimation will increase 302 with the number of segments that constitute a whole dike, but will decrease for increasingly 303 overlapping segments and higher rotation angle between the segment direction and that of the 304 main dyke (Pollard et al., 1982). Overlapping segments will also tend to induce segment 305 asymmetry as well as pinching or thinning of the edges (Pollard et al. 1982). This could 306 potentially explain the extremely high stress gradients derived from Pollard and Muller's analysis 307 as well as some of the pinched segment profiles. However this cannot explain the overall, 308 general shape pattern displayed by both the Rum and Swartruggens dikes: all these dikes appear 309 fatter at their edges than predicted by both Pollard and Muller's and the segmented analyses, and 310 they would appear even fatter for overlapping, pinching segments.

312 Considering all these limitations and effects together, it seems our single dike analysis would 313 overestimate overpressures by at most a factor 10, and appears to be the best analytical method 314 for fitting the measured profiles. Therefore, treating each segment as an individual dike provides 315 a fairer assessment of their overpressure, stress gradient and shape. 
318 The elastic model of Pollard and Muller (1976) fits the data poorly for most of our studied dikes.

319 The first mismatch between the data and the elastic model is the calculated values of 320 overpressure and stress gradient which are very large. This is evident from the comparison with 321 the values estimated in previous studies (Table 1) (Geshi et al. 2010, Poland et al. 2008, Pollard 322 and Muller 1976). The overpressures are especially large and likely unphysical for the Rum 323 dikes, while the Swartruggens dikes' values are large but more plausible. The stress and 324 overpressure gradients calculated are mostly implausible for both examples. If the Rum dikes with lengths $<1 \mathrm{~m}$ are neglected, the range of estimated overpressure values is unchanged ( 37 $3261990 \mathrm{MPa}$ ), although the average is slightly reduced to $398 \mathrm{MPa}$. If the Rum dikes with 327 thicknesses $<0.05 \mathrm{~m}$ are neglected, the estimated values of overpressure are $70-1990 \mathrm{MPa}$, 328 averaging $710 \mathrm{MPa}$. There appears therefore to be no dependence of these results on dike size. 329 One could reduce these overpressure and stress gradient estimates by up to an order of 330 magnitude if we consider each dyke individually and not as segments from a larger dike (see 331 previous section). Yet the majority of these estimates remain much higher than values reported in 332 previous studies (Table 1).

Very high values of overpressures and stress gradients cannot be explained using an elastic model. A rock's tensile and compressive strengths are typically of order $10 \mathrm{MPa}$ and $50 \mathrm{MPa}$ respectively, whilst magma overpressures have been estimated at $<20 \mathrm{MPa}$ (Stasiuk et al. 1993, 337 Gudmundsson 1999). For a $20 \mathrm{MPa}$ magma source overpressure (the magma pressure in excess of the regional, compressive tectonic stress), a dike propagating $1 \mathrm{~km}$ from its source would experience a regional stress gradient of $\leq 20 \mathrm{kPa} \mathrm{m}^{-1}$ (Jaupart and Allegre 1991) and this stress gradient estimate would decrease as the dike propagates further from its source. A dike driven by 
buoyancy would have a driving stress gradient of $\Delta \rho g$, where $\Delta \rho$ is the density difference between the magma and the host rocks and $g$ is the gravitational acceleration. A magma-host density difference of $100 \mathrm{~kg} \mathrm{~m}^{-3}$ gives a stress gradient of only $1 \mathrm{kPa} \mathrm{m}^{-1}$. Stress gradients as high as those estimated for the Rum and Swartruggens dikes would therefore necessitate magma buoyancies greatly in excess of natural values governed by density differences between magmas and host rocks.

The fracture toughness of a rock is important in terms of the dike opening. According to Linear Elastic Fracture Mechanics, the intrusion of magma into a rock requires the concentration of stress at the intrusion tip to exceed the fracture toughness $\mathrm{K}_{\mathrm{c}}$ of that rock (Pollard, 1987). This is equivalent to having an overpressure greater than $\sim \mathrm{K}_{\mathrm{c}} /(\mathrm{L})^{1 / 2}$, where $\mathrm{L}$ is the length of the magma-filled crack. Rocks with higher fracture toughness both require higher magma overpressure for the dikes to propagate and induce greater blunting of the dikes at their tip. Laboratory measurements of fracture toughness give values on the order of 1-10 MPa $\mathrm{m}^{1 / 2}$, and so kilometer-long dikes would be expected to propagate with overpressures of $1 \mathrm{MPa}$. Larger dikes would require even lower overpressures. Conversely, our estimated overpressures would suggest rock fracture toughness of the order $10-10^{4} \mathrm{MPa} \mathrm{m}^{1 / 2}$ and $10^{2}-10^{3} \mathrm{MPa} \mathrm{m}^{1 / 2}$ for the Rum and Swartruggens dikes, respectively. These are much higher values than measured in the laboratory (e.g. Schmidt and Huddle, 1977), but similar to other field-based fracture toughness estimates (Delaney and Pollard, 1981; Delaney et al., 1986; Reches and Fink, 1988, Gudmundsson 2009). Such high values are either explained by large confining pressures at the time of dike intrusions or extensive inelastic deformation ahead and around the dike tip (Delaney et al., 1986; Rubin, 1993; Fialko and Rubin, 1997). The former explanation would necessitate depths of intrusion 
greater than that of the Rum and Swartruggens dikes, whilst the latter explanation is plausible but requires extensive inelastic deformation.

367 Various non-elastic explanations could be invoked to explain the high estimated overpressure 368 and stress gradient values. If the elastic parameter values used in the model were too large, the 369 overpressures and stress gradients would be overestimated. Dikes may form through the dilation 370 of pre-existing fractures that are suitably orientated with regards to principal stress directions 371 (e.g. Gudmundsson 1984, Delaney et al. 1986, Valentine and Krogh 2006), reducing the stress 372 required to fracture the host-rock. Once a fracture is re-sealed, the probability of a fracture 373 reinitiating in the same location is greater (the host-rock's compliance) and the shear modulus of 374 the rock can be reduced by a factor of 2 or 3 (Worthington and Lubbe 2007, Kavanagh 2010), 375 effectively making the crust less rigid. For the Rum dikes showing evidence of intruding host376 rocks with many pre-existing joints, the compliance may have been significant. The opening of a

377 dike is linearly proportional to its overpressure and inversely proportional to the shear modulus 378 of the host rocks (e.g. Pollard, 1987). Therefore, accounting for the compliance can only partly 379 explain the large overpressures estimated for the Rum dikes; typical changes in elastic properties 380 due to compliance would only alter the calculated values by about a factor of 3 in the Rum and

381 Swartruggens cases.

Magma extrusion from a greatly pressurised chamber into surrounding rock also provides an 384 explanation for high calculated overpressures, particularly on Rum. Magma chamber overpressure increases during edifice growth until edifice destruction occurs (Pinel and Jaupart 2000, Pinel and Jaupart 2003, Pinel and Jaupart 2004). The Rum dikes may represent magma 
extrusion from a chamber during the high-overpressure edifice-building stage. Typical stratovolcanic cones exert a load of approximately $50 \mathrm{MPa}$, significantly affecting the rock

389 stresses beneath the volcanic edifice (Pinel and Jaupart 2003). Edifice size strongly affects the

390 critical magma overpressure required for eruption, which may be much larger than the host-rock

391 tensile strength (Pinel and Jaupart 2003). This is a more plausible model for explaining some of 392 the overpressures calculated for the Rum dikes as a volcanic edifice was present at the time of 393 diking.

High overpressures may also be partly attributed to shear failure. Assuming a shear component is present whilst diking occurs, dikes may tend to be wider than otherwise expected, leading to higher calculated overpressures. A shear component could be caused along the dike length if intrusion occurs in an orientation divergent from $\sigma_{1}$, as would be likely when intruding preexisting joints. This is consistent with the offset and overlapping dike segment pattern commonly seen on Rum, suggesting propagation along non-principal stress directions.

Both Rum and Swartruggens dikes give very high calculated stress gradient values, much larger than the values estimated from previous studies (Table 1). Assuming constant elastic properties and local horizontal magma pressure, the calculated stress gradients represent mainly horizontal gradients in crustal stress. Taking a calculated stress gradient value of $65 \mathrm{kPa} \mathrm{m}^{-1}$ for a Swartuggens dike, the crustal stress normal to the dike would change by $65 \mathrm{MPa}$ over a $1 \mathrm{~km}$ region, an implausibly large horizontal value in the upper crust. This stress gradient would require a surface topography change of about $3 \mathrm{~km}$, which is unlikely in this region of southern 
409 Africa. The Rum dikes give calculated stress gradients that are two orders of magnitude larger;

410 even with very strong lateral stress gradients, these values are extremely large.

412 A lateral variation in host rock properties has also been invoked in order to explain stress 413 gradient values (e.g. Pollard and Muller 1976, Kavanagh and Sparks 2011) as well as variations 414 in dike thickness (e.g. Baer 1991, Geshi et al. 2010). This is unlikely to be the cause of the high 415 stress gradients estimated for the Rum dikes as these intruded within one rock unit; variations in 416 burial depth along their strike would also be too small to have a significant effect. 417 Heterogeneities in the sandstone layers may add to the variations in dike thickness of the Rum 418 dikes. However, the majority have a small enough scale that even the properties of the single 419 rock unit are unlikely to have changed significantly. Variable host rock properties are thus 420 unlikely to have caused the thickness variations or the stress gradient values measured on Rum.

422 The cause of the dike asymmetry is most likely due to host-rock inelasticity, small scale lateral 423 host-rock property variations, and most importantly, the interference of dike edges and 424 overlapping segments. Successive emplacement of neighbouring dikes and dike segments will 425 alter the stress distribution in the host rock (e.g. Rubin and Pollard 1987). Overlapping segments 426 with solidified magma pinning the dike edges in position is the likely cause of the asymmetry 427 seen.

429 The dike shape

430 Changing the elastic parameters in the model does not improve the overall fit because of the mismatch between the predicted and observed dike shape. The modelled dike thickness is 
overestimated at the centre and mostly underestimated at the edges (Figure 5). Most of the dikes measured had a flatter central section than predicted. An active dike's width is determined by the overpressure which usually declines with time as the chamber pressure decreases, manifest by waning flow rate in many lava eruptions (Stasiuk et al. 1993), although the thickness can also be determined by the dike length for a fixed overpressure. If a dike erupts, this dike and the overall, not-yet-solidified, intrusive system will experience a reduction in overpressure. However, the majority of dikes are not thought to erupt (e.g. Gudmundsson 1984, Gudmundsson et al. 1999). Arrested dikes can still however experience a reduction in overpressure during intrusion. At neither of the studied field localities were we able to find unequivocal field evidence of the magma transport direction; these may therefore have propagated vertically or laterally. For a constant magma volume, provided that the crack is not buoyancy driven, the overpressure in an intruding crack will decrease as the length of the crack increases (Mcleod and Tait 1999). Moreover, however the intrusion is driven, its overpressure will decrease because of the viscous pressure drop it will experience during propagation (Lister and Kerr, 1991). We do not see direct evidence that the dikes from either locality connected to their palaeosurface, and therefore we must rely on indirect evidence to assess whether or not these dikes were feeders. If it can be assumed that at tens of meters depth a dike with a maximum thickness greater than one meter has the potential to act as a feeder dike (Geshi et al. 2010), the Swartruggens dike segments (which have a maximum thickness of 1.95 meters; Kavanagh and Sparks, 2011) could potentially have acted as feeder dikes. As the mean thickness of the dikes measured at both field locations is less than one meter, it is assumed that our analysis can only be applied to dikes fulfilling this criterion, and the application of our results to thicker dikes will require further investigation. 
457 dike edges adds to this effect. As the overpressure wanes, if the position of the edges becomes

458 fixed and the dike is no longer propagating in the direction of the tip, the preserved thickness is

459 then determined by the initial overpressure (Figure 9C). However, the non-solid and less viscous

As magma flows through a fracture (Figure 9A), chilling of the magma at the dike margins prevents it from closing at the tips (Figure 9B). Viscosity increase by preferential cooling at the central parts of the dike can close as the overpressure declines; the initial dike injection shape is not the shape that is ultimately preserved as the solidified dike. We suggest therefore that the shape mismatch is principally a result of chilling and solidification during dike emplacement.

Inelasticity can also account for some of the dike thickness variation. There is strong evidence for inelastic deformation in the zones between the Swartruggens dike segments, which may have reduced the host-rock rigidity and shear strength. Mechanical processes such as brecciation, stoping and weathering (preferentially focused at dike termination points, over-laps and relay zones) can weaken the rocks prior to magma emplacement and produce an inelastic host-rock response during emplacement (Brown et al. 2007, Kavanagh 2010, Kavanagh and Sparks, 2011). Similar inelastic deformation between adjacent segments has been observed by Schofield et al. (2010) at the Golden Valley Sill, South Africa. Additionally, small segments such as those observed on Rum are likely to correspond to segments lying close to the very tip of their main dike, and so to be embedded within the inelastic, damaged region that surrounds that main dyke tip. Indeed, the size of this damage region tends to scale with that of the dyke that created it (Faulkner et al., 2011), and could reach several meters or tens of meters (e.g. Delaney et al., 1986). Inelastic deformation within the damage zone would contribute to blunting the edges of the segments embedded there. Thus inelastic deformation could both explain the apparent high 
478 values of rock fracture toughness, suggested by our high overpressure estimates, and the 479 observations of dike tips that are thicker than expected from elastic theory. Inelastic deformation 480 in the steps between segments also provides an explanation for those dikes which are markedly 481 asymmetric. Much more inelastic deformation at one end of the dike than the other will mean a 482 distortion of the shape that results in asymmetry. The observation of alternations in the sense of 483 asymmetry of segments indicates too that complex inelastic deformation in the step-over regions 484 has occurred.

$486 \quad$ Implications for eruption longevity and crustal strain

487 The tendency for thick dike tips and narrow centers has broader implications. The wedging of the 488 dike edges formed at high magma overpressures is made permanent by chilling. Thus as the 489 pressure reduces and the eruption wanes, the fracture will be prevented from closing fully and 490 the dike can continue to act as an open conduit for longer than it otherwise would have been able 491 to. Dike emplacement can be regarded as the accommodation of crustal strain as a response to 492 tectonic stresses. However, the dimensions of an active dike with magma pressures exceeding 493 tectonic stresses indicate that the transient strain can exceed the tectonic strain expected. Since 494 the now chilled edges have previously been pushed apart under a high magma overpressure, the 495 additional strain can be permanently preserved due to the chilled and wedged dike edges. For 496 large dikes with prolonged flow at overpressures exceeding tectonic stresses and with substantial 497 solidification along the dike edges the excess strain could be substantial.

\section{$499 \quad$ 7. Conclusions}


500 Many of the dikes measured on Rum and at Helam Mine are poorly fit by the classical elastic 501 model of Pollard and Muller (1976). There are two distinct mismatches between the presented 502 data and the elastic model. Firstly, many dike shapes are too thin in the middle and too thick at 503 the edges to be fit by an elastic profile; the calculated $\mathrm{R}^{2}$ values range from $0.389-0.997$ and the 504 misfits are larger than measurement uncertainties. Secondly, even for dikes where the model fit 505 is acceptable, the calculated magma driving pressures and linear stress gradients are very large, 506 particularly for the small-scale basaltic dikes on Rum. Many explanations have been provided to 507 account for the differences. Of these, the cooling of the dike edges wedging the fracture open, 508 and the host-rock inelastic deformation pre- and syn- magma emplacement provide the most 509 complete explanation for the mismatches between the data and the model. Care should be taken 510 when extrapolating the observations from the dikes measured from the Swartruggens swarm and 511 on Rum. As the mean observed dike thickness was less than a meter, it is not automatic to 512 assume that the analysis will apply to larger dikes; the application of the results to thicker dikes 513 will require further investigation.

\section{Acknowledgements}

516 KAD would like to thank R. C. Ogilvie-Harris for assistance with the Rum data collection. A. 517 Gudmundsson, A. E. L. Ferrari and an anonymous reviewer are gratefully acknowledged for 518 providing valuable comments to improve the manuscript. M. Poland and two anonymous 519 reviewers are thanked for helpful comments on an earlier shorter form of the manuscript. J. 520 Davidson and A. Rogers are thanked for permission to publish the dataset from Helam Mine. 
522 by an advanced grant from the European Research Council. KAD was supported by a NERC

523 Consortium Grant.

524

525 


\section{$526 \quad$ References}

527 Allsopp, H.L. \& Barrett, D.R. 1975. Rb-Sr age determinations on South African kimberlite 528 pipes. Physics and Chemistry of the Earth, 9, 605-617.

529 Baer, G., 1991. Mechanisms of dike propagation in layered rocks and in massive, porous 530 sedimentary rocks. Journal of Geophysical Research 96, 11911-11929.

531 Basson, I. J., and Viola, G., 2003. Structural overview of selected Group II kimberlite dyke 532 arrays in South Africa: implications for kimberlite emplacement mechanisms. South African 533 Journal of Geology 106 (4), 375 - 394.

534 Brown, R. J., Kavanagh, J. L., Sparks, R. S. J., Tait, M., and Field, M., 2007. Mechanically 535 disrupted and chemically weakened zones in segmented dike systems cause vent localization:

536 Evidence from kimberlite volcanic systems. Geology 35 (9), 815 - 818.

537 Buck, W. R., Einarsson, P., and Brandsdottir, B., 2006, Tectonic stress and magma chamber size 538 as controls on dike propagation: constraints from the 1975-1984 Krafla rifting episode: Journal of 539 Geophysical Research, v. 111, doi:10.1029/2005JB003879.

540 Delaney, P. T., and Pollard, D. D., 1981. Deformation of host rocks and flow of magma during 541 growth of Minette dikes and breccias-bearing intrusions near Ship Rock, New Mexico. U. S. 542 Geological Survey professional paper 1202.

543 Delaney, P. T., Pollard, D. D., Ziony, J. I., and McKee, E. H., 1986. Field relations between 544 dykes and joints' emplacement processes and paleostress analysis. Journal of Geophysical $545 \quad$ Research 91 (B5), 4920 - 4938.

546 Domenico, S. N., 1983. Sandstone and limestone porosity determination from shear and 547 compressional wave velocity. Bulletin of the Australian Society of Exploration Geophysicists 14 $548(4), 81-90$. 
549 Emeleus, C. H., 1997. Geology of Rum and the adjacent islands. British Geological Survey 550 Memoir for 1:50 000 Geological Sheet 60 (Scotland). The Stationery Office.

551 Faulkner, D. R., Mitchell, T. M., Jensen, E., and Cembrano, J., 2011. Scaling of fault damage 552 zones with displacement and the implications for fault growth processes. Journal of Geophysical 553 Research 116, B05403, doi:10.1029/2010JB007788.

554 Fialko, Y. A., and Rubin, A. M., 1997. Numerical simulation of high-pressure rock tensile 555 fracture experiments: evidence of an increase in fracture energy with pressure? Journal of 556 Geophysical Research 102 (B3), $5231-5242$.

557 Geshi, N., Kusumoto, S., and Gudmundsson, A., 2010. Geometric difference between non-feeder 558 and feeder dikes. Geology 38 (3), 195-198.

559 Gudmundsson, A., 1983. Form and dimensions of dykes in Eastern Iceland. Tectonophysics 95, $560295-307$.

561 Gudmundsson, A., 1984. Formation of Dykes, Feeder-dykes, and the Intrusion of Dykes from 562 Magma Chambers. Bulletin of Volcanology 47 (3), 537 - 550.

563 Gudmundsson, A., 1999. Fluid overpressure and stress drop in fault zones. Geophysical Research 564 Letters $26(1), 115-118$.

565 Gudmundsson, A., 2009. Toughness and failure of volcanic edifices. Tectonophysics 471, 27 56635.

567 Gudmundsson, A., 2011. Rock Fractures in Geological Processes. Cambridge University Press, 568 pp.592.

569 Gudmundsson, A. Marinoni, L. B., and Marti, J., 1999, Injection and arrest if dykes: Implications 570 for volcanic hazards. Journal of Volcanology Geothermal Research 88, 1 - 13. 
571 Gurney, J. J., and Kirkley, M. B., 1996. Kimberlite dyke mining in South Africa. Africa

572 Geoscience Review 3, 191 - 201.

573 Hamilton, M. A., Pearson, D. G., Thompson, R. N., Kelley, S. P., and Emeleus, C. H., 1998.

574 Rapid eruption of Skye lavas inferred from precise UPb and ArAr dating of the Rum and Cuillin

575 plutonic complexes. Nature 394, $260-263$.

576 Jaupart, C., and Allègre, C. J., 1991. Gas content, eruption rate and instabilities of eruption

577 regime in silicic volcanoes. Earth and Planetary Science Letters 102, 413 - 429.

578 Kavanagh, J., 2010. Ascent and emplacement of kimberlite magmas, PhD Thesis, University of

579 Bristol.

580 Kavanagh J., and Sparks, R. S. J., 2011. Insights of dyke emplacement mechanics from detailed

581 3D dyke thickness datasets. Journal of the Geological Society of London 168, $965-978$.

582 Kerr, R. C., and Lister, J. R., 1995. The lateral intrusion of silicic magmas into unconsolidated

583 sediments: the Tennant Creek prophyry revisited. Australian Journal of Earth Sciences 42, 223 -

584224.

585 Khazanehdari, J., and Sothcott, J., 2003. Variation in dynamic elastic shear modulus of sandstone

586 upon fluid saturation and substitution. Geophysics 68 (2), 472 - 481.

587 Landau, L. D., and Lifshitz, E. M., 1986. Theory of Elasticity, 3rd edition. Butterworth

588 Heinemann, Oxford, England.

589 Lister, J. R., and Kerr, R. C., 1991. Steady solutions for feeder dykes in a density-stratified

590 lithosphere. Journal of Geophysical Research 96, (B6), 10049 - 10077.

591 McLeod, P., and Tait, S., 1999. The growth of dykes from magma chambers. Journal of

592 Volcanology and Geothermal Research 92, 231-245 
593

594

595

596

597 (B11), 2306.

598 Menand, T., and Tait, S. R., 2001. A phenomenological model for precursor volcanic eruptions.

599 Nature 411, 678-680.

600 Meriaux. C., and Lister, J. R., 2002. Calculation of dike trajectories from volcanic centres.

601 Journal of Geophysical Research 107 (B4), 2077.

602 Nicoll, G. R., Holness, M. B., Troll, V. R., Donaldson, C. H., Holohan, E. P., Emeleus, C. H., 603 and Chew, D., 2009. Early mafic magmatism and crustal anatexis on the Isle of Rum: evidence 604 from the Am M`am intrusion breccia. Geological Magazine 146 (3), 368-381.

605 Phillips, D. 1991. Argon isotope and halogen chemistry of phlogopite from South African 606 kimberlites: a combined step-heating, laser probe, electron microprobe and TEM study. Chemical 607 Geology: Isotope Geoscience Section, 87, 71-98.

608 Pinel, V., and Jaupart, C., 2000. The effect of edifice load on magma ascent beneath a volcano.

609 Philosophical Transactions of the Royal Society of London A 358, 1515 - 1532.

610 Pinel, V., and Jaupart, C., 2003. Magma chamber behaviour beneath a volcanic edifice. Journal 611 of Geophysical Research 108 (B2), 2072.

612 Pinel, V., and Jaupart, C., 2004. Magma storage and horizontal dyke injection beneath a volcanic 613 edifice. Earth and Planetary Science Letters 221, 245 - 262. 
614 Poland, M., Moats, W. P., and Fink, J. H., 2008. A model for radial dike emplacement in 615 composite cones based on observations from Summer Coon volcano, Colorado, USA. Bulletin of 616 Volcanology 70, 861-875.

617 Pollard, D. D., 1987. Elementary fracture mechanics applied to the structural interpretation of 618 dykes; in Mafic dyke swarms, Editors: Halls, H. C., and Fahrig, W. F., Geological Association of 619 Canada Special Paper 34, 5-24.

620 Pollard, D. D., and Muller, O. H., 1976. The effect of gradients in regional stress and magma 621 pressure on the form of sheet intrusions in cross section. Journal of Geophysical Research 81, (5), $622975-984$.

623 Pollard, D. D., Segall, P. and Delaney, P. T., 1982. Formation and interpretation of dilatant 624 echelon cracks. Geological Society of America Bulletin, 93, 1291-1303.

625 Ray, R. Hetu, C. S., and Jyotirmoy, M., 2007. Structure and emplacement of the Nandurbar626 Dhule mafic dyke swarm, Deccan Traps, and the tectonomagmatic evolution of flood basalts. 627 Bulletin of Volcanology 69, $537-551$.

628 Reches, Z., and Fink, J., 1988. The mechanism of intrusion of the Inyo Dike, Long Valley 629 Caldera, California. Journal of Geophysical Research 93 (B5), 4321 - 4334.

630 Roman, D. C., and Cashman, K. V., 2006. The origin of volcano-tectonic earthquake swarms. 631 Geology $34(6), 457-460$.

632 Rubin, A. M., 1993. Tensile fracture of rocks at high confining pressure: Implications for dike 633 propagation. Journal of Geophysical Research 98 (B9), 15,919 - 15,935.

634 Rubin, A. M., 1995. Propagation of magma-filled cracks. Annual Reviews in Earth and Planetary 635 Science 23, $287-336$. 
636 Rubin, A. M., and Pollard, D. D., 1987. Origins of blade-like dikes in volcanic rift zones, in:

637 Decker, R. W., Wright, T. L., and Stauffer, P. H., eds., Volcanism in Hawaii. U.S. Geological 638 Survey professional paper 1350, 1449-1470.

639 Tada, H., Paris, P. C., and Irwin, G. R., 2000. The Stress Analysis of Cracks Handbook, 3rd ed., 640 New York : ASME Press.

641 Timoshenko, S. P., and Goodier, J. N., 1970. Theory of elasticity. McGraw-Hill, $3^{\text {rd }}$ edition, pp.1642567.

643 Schmidt, R.A. and Huddle, C.W., 1977. Effect of confining pressure on fracture toughness of 644 Indiana limestone. International Journal of Rock Mechanics \& Mining Sciences Geomechanics 645 Abstracts 14, $289-293$.

646 Schofield, N., Stevenson, C., and Reston, T., 2010. Magma fingers and host rock fluidization in 647 the emplacement of sills. Geology 38, $63-66$.

648 Sneddon, I. N., 1946. The distribution of stress in the neighborhood of a crack in an elastic solid. 649 Proceedings of the Royal Society of London A 187, 229 - 260.

650 Stasiuk, M. V., Jaupart, C., and Sparks, R. S. J., 1993. Influence of cooling on lava-flow 651 dynamics. Geology $21(4), 335-338$.

652 Valentine, G. A., and Krogh, K. E. C., 2006. Emplacement of shallow dikes and sills beneath a 653 small basaltic volcanic center: The role of pre-existing structure (Paiute Ridge, southern Nevada, 654 USA). Earth and Planetary Science Letters 246, 217 - 230.

655 White, R.S., Drew, J., Martens, H.R., Key, J., Soosalu, H. and Jakobsdóttir, S.S, 2011. 656 Dynamics of dyke intrusion in the mid-crust of Iceland. Earth and Planetary Science Letters $657304,300-312$ 
658 Worthington, M. H., and Lubbe, R., 2007. The scaling of fracture compliance. Geological 659 Society, London, Special Publications 270, $73-82$.

660

\section{Table caption:}

662 Table 1: Estimated values for driving pressure $\left(\mathrm{P}_{\mathrm{o}}-\mathrm{S}_{\mathrm{y}}\right)$ and stress gradient $(\nabla \mathrm{P}-\nabla$ Sy) for Rum 663 and Swartruggens dikes (this study), non-feeder dikes at Miyakejima volcano (Geshi et al. 2010), 664 silicic dikes at Summer Coon volcano (Poland et al. 2008) and Walsen Dike and Theatre Canyon 665 Sill (Pollard and Muller 1976).

666

\section{$667 \quad$ Figure captions}

668 Figure 1: The locations of the measured dikes. A generalised geological map of the isle of Rum 669 with each of the dike measurement localities highlighted.

670

671 Figure 2: Photographs and sketches of Rum dikes. A) Plan-view of dike with crack tips showing 672 pronounced chilled margins. One crack tip shows infilling with sediment. There is overlap 673 between dike segments, one segment shows an apparent skew. B) Dike orientation unaffected by 674 secondary jointing. C) Joint affected dike orientation.

675

676 Figure 3: A) Surface outcrop map of the John and Edward kimberlite dike segments, Helam 677 Mine, South Africa. B) Contour plot of dike thickness for the John and Edward dike segments 678 plotted against depth below the current surface and distance easting. The shaded area indicates 679 locations where data has been collected. The approximate stratigraphy and unit contacts (dashed 
680 line) are shown, comprising quartzite (Qtz), shale (Sh) and dolerite (Dol). The map inset 681 indicates the location of Helam Mine in southern Africa (lat $-25.594^{\circ}$, lon $26.659^{\circ}$ ).

683 Figure 4: Thickness versus length profile of Rum (Figures 3A, C and D) and Swartruggens 684 (John's dike segment, 18th Level) (Figure 3B) dikes. A best-fit model (line) is plotted through 685 the data (diamonds). Both datasets show asymmetrical dike-thicknesses, with fatter edges and 686 thinner middles compared to the elastic model. Best-fit model parameter values are: A), C) and 687 D) $\mathrm{G}=15.4 \mathrm{GPa}$ (Khazanehdari and Sothcott, 2003), $v=0.215$ (Domenico, 1983), $\Delta \mathrm{P}=367$ $\mathrm{MPa}$, and $\nabla \mathrm{P}=48 \mathrm{MPa} \mathrm{m}^{-1}$. B) $\mathrm{G}=40 \mathrm{GPa}, \Delta \mathrm{P}=34 \mathrm{MPa}$ and $\nabla \mathrm{P}=65 \mathrm{kPa} \mathrm{m}^{-1} . \mathrm{L}^{*}$ is the alongdike distance normalised by the dike length and $\mathrm{T}^{*}$ is the half-thickness normalised by the dike 690 length.

691

Figure 5: A) to D) $\mathrm{T}$ is dike thickness. The line at $\mathrm{y}=0$ is a perfect model fit to the data. Negative $693 \mathrm{y}$-axis values indicate a dike that is fatter than the model, positive y-axis values show a thinner 694 dike than the model. Positive values are in the downwards direction. Both A) and C) the Rum 695 dikes and B) and D) the Swartruggens dikes (John segment, Levels 16-21, and Edward segment 696 Levels 19-22) have fatter edges and thinner centres than is expected from the model fit. Figure 697 4C) and D) as 4A) and B), but with the vertical axis changed to show the range of -2 to 2 in order 698 to more clearly see the distribution of the points above and below the perfect model fit (red) line. 699 It can be seen that for both field localities, the majority of the points in the central region $\left(\mathrm{L}^{*}=-\right.$ 0.3 to 0.3$)$ show thicknesses which are narrower than expected, and at the edges $\left(L^{*}<-0.3\right.$ and $701>0.3)$ the thicknesses are larger than expected. Frequency histograms of the difference between the modelled $\mathrm{T}$ and the measured $\mathrm{T}$ for $\mathrm{E}$ ) the Rum and F) Swartruggens dikes showing the 
distribution of data relative to 0 (the perfect model fit) for the central region of each dike (red)

704 and the edges of each dike (black).

706 Figure 6: A and B) The relationship between dike tips of segmented and non-segmented dikes.

707 A) The tip of a dike with no neighboring dikes or dike segments (Rum). B) The overlapping dike 708 tips of two segmented dikes observed at locality 5 on Rum. The dike tips are separated at this 709 locality by approximately $10 \mathrm{~cm}$.

710

711 Figure 7: A) Schematic diagram of a segmented dike. All the segments are identical, collinear, 712 equally spaced, and loaded with the same overpressure. Two segments are represented here, but 713 the analysis considers an infinite number of segments. B) Along-strike opening of the dike 714 segments. The along-strike position $x$, measured from the segment center, is normalized to the 715 segment half-length $a$, and the segment opening $u_{s}$ to the maximum opening, $\Delta P(1-v) a / G$, of a 716 single dike with the same half-length and overpressure $\Delta P$. The tip-to-tip distance $d$ between 717 adjacent dike segments is normalized to the length of the segments: $s=d / 2 a$. Only half of the 718 segment length is shown $\left(0<L^{*}<0.5\right)$. The continuous curve corresponds to the case of a single 719 dike, and the dashed curves to different normalized spacings $s$.

721 Figure 8: Opening profiles of two segments belonging to the same dike from the Isle of Rum 722 (diamonds) compared with the segmented analysis (equation 3; black curve) and the analysis of 723 Pollard and Muller (1976; dashed curve). A) Best overpressure estimates: $110 \mathrm{MPa}$ (black curve) 724 and $332 \mathrm{MPa}$ (dashed curve). There is no stress gradient. B) Best overpressure estimates: 73 $725 \mathrm{MPa}$ (black curve) and $150 \mathrm{MPa}$ (dashed curve). The segmented analysis cannot explain the 
726 teardrop shape of this segment. Best stress gradient estimated from Pollard and Muller's analysis

727 (dashed curve): $136 \mathrm{MPa} / \mathrm{m}$.

728

729 Figure 9: Schematic illustration of the impact of cooling on preserved dike geometry, presented 730 as three time steps in the evolution of a horizontal section through the dike. A) Magma intrudes 731 a fracture, and B) cooling ensues at the dike margins. C) Chilled fracture tip magma props the 732 fracture open as the overpressure reduces, preventing crack closure and creating the observed 733 dike profile (solid line) with a thinner center and thicker tips. The dashed line in C) indicates the 734 expected profile of a pressurized magma-filled fracture in an elastic media.

735 


\begin{tabular}{l|cc}
\hline Intrusive Body & Number of observations & $P_{o}-S_{y o}(\mathrm{MPa})$ \\
\hline Rum dikes & 784 & $37-1990$ \\
Swartruggens dikes & 1387 & $4-40$ \\
Miyakejima volcano & $>88$ & $7-12$ \\
Summer Coon volcano & 238 & $4.6-148.3$ \\
Walsen Dike & 256 & $0.35-4.8$ \\
Theatre Canyon Sill & 44 & $3.6-50$ \\
\hline
\end{tabular}




\begin{tabular}{c}
\hline$\nabla P-\nabla S_{y}\left(\mathrm{kPa} \mathrm{m}^{-1}\right)$ \\
\hline $0-3 \times 10^{6}$ \\
$15-87$ \\
--- \\
$0.003-0.133$ \\
$-0.052--0.71$ \\
$-8.4--12$ \\
\hline
\end{tabular}


Figure1_Daniels

Click here to downtoadFigure:FIGURE1_Daniels.pdf

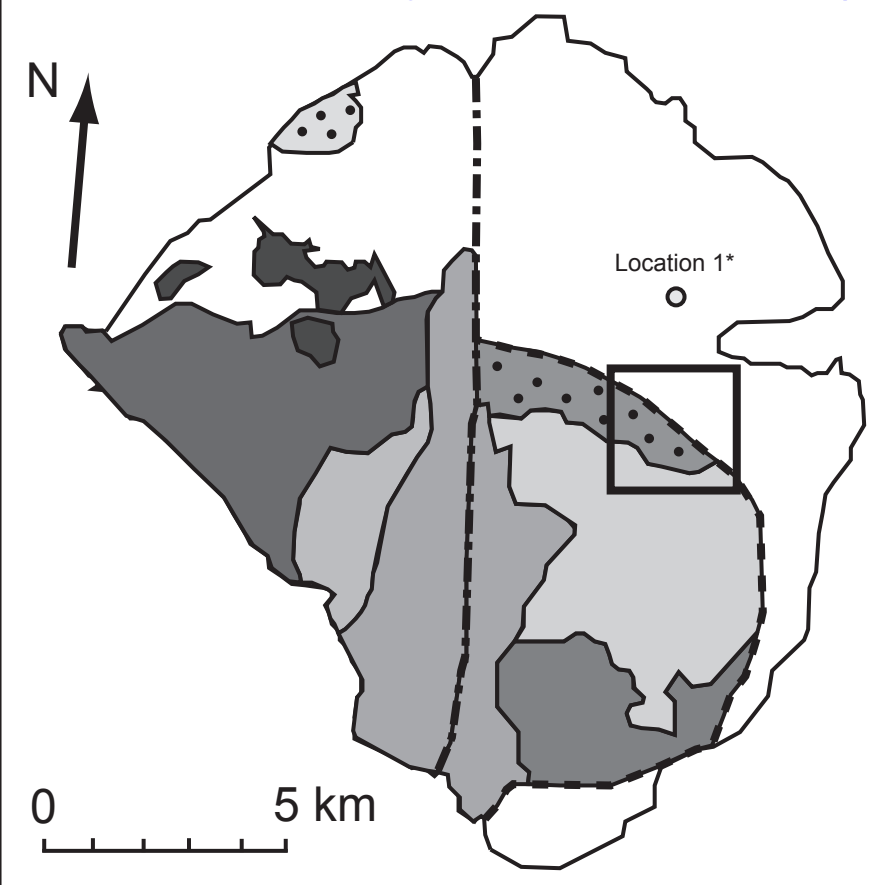

Key:

PALAEOGENE VOLCANICS

$\square$ Canna Lava Formation

RUM CENTRAL COMPLEX

$\square$ Western Granite

$\square$ Southern Marginal Zone

•. Northern Marginal Zone

$\square$ Central Intrusion

$\square$ Western Layered Intrusion

Layered Suite

$\square$ Eastern Layered Intrusion

PRE-PALAEOGENE SEDIMENTS

- Triassic sediments

$\square$ Torridonian Group

- _ Long Loch Fault

- - - Main Ring Fault

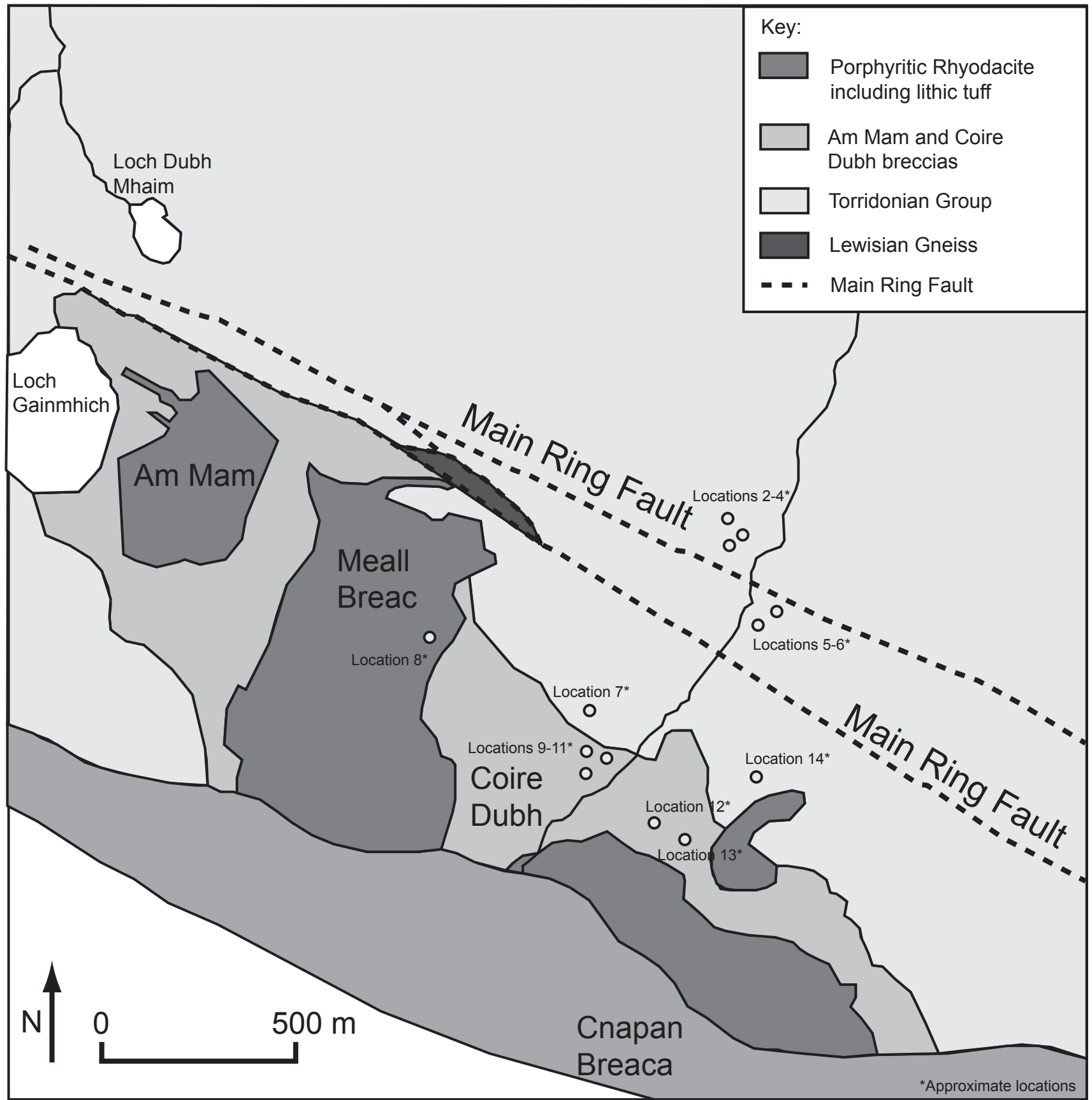




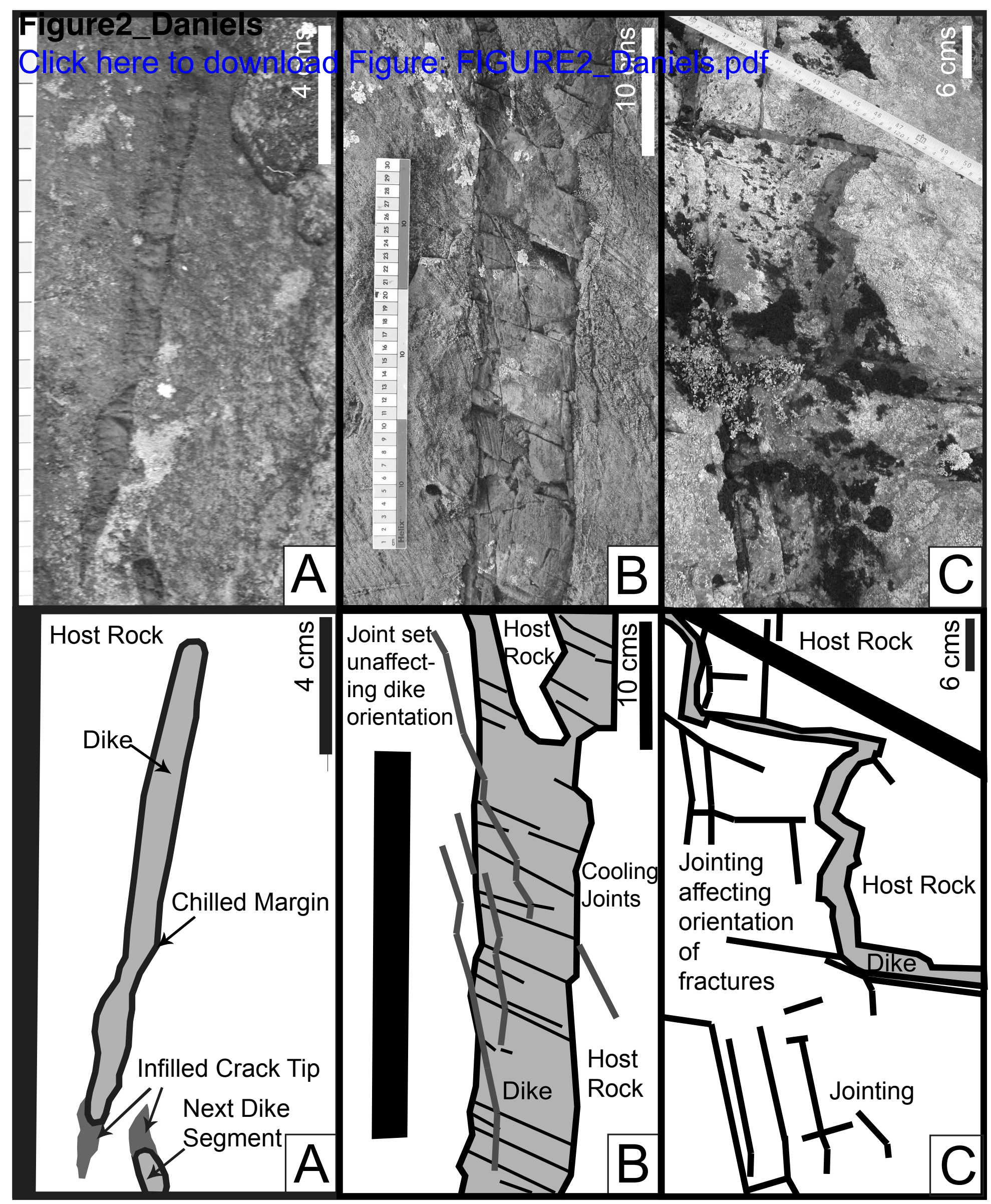




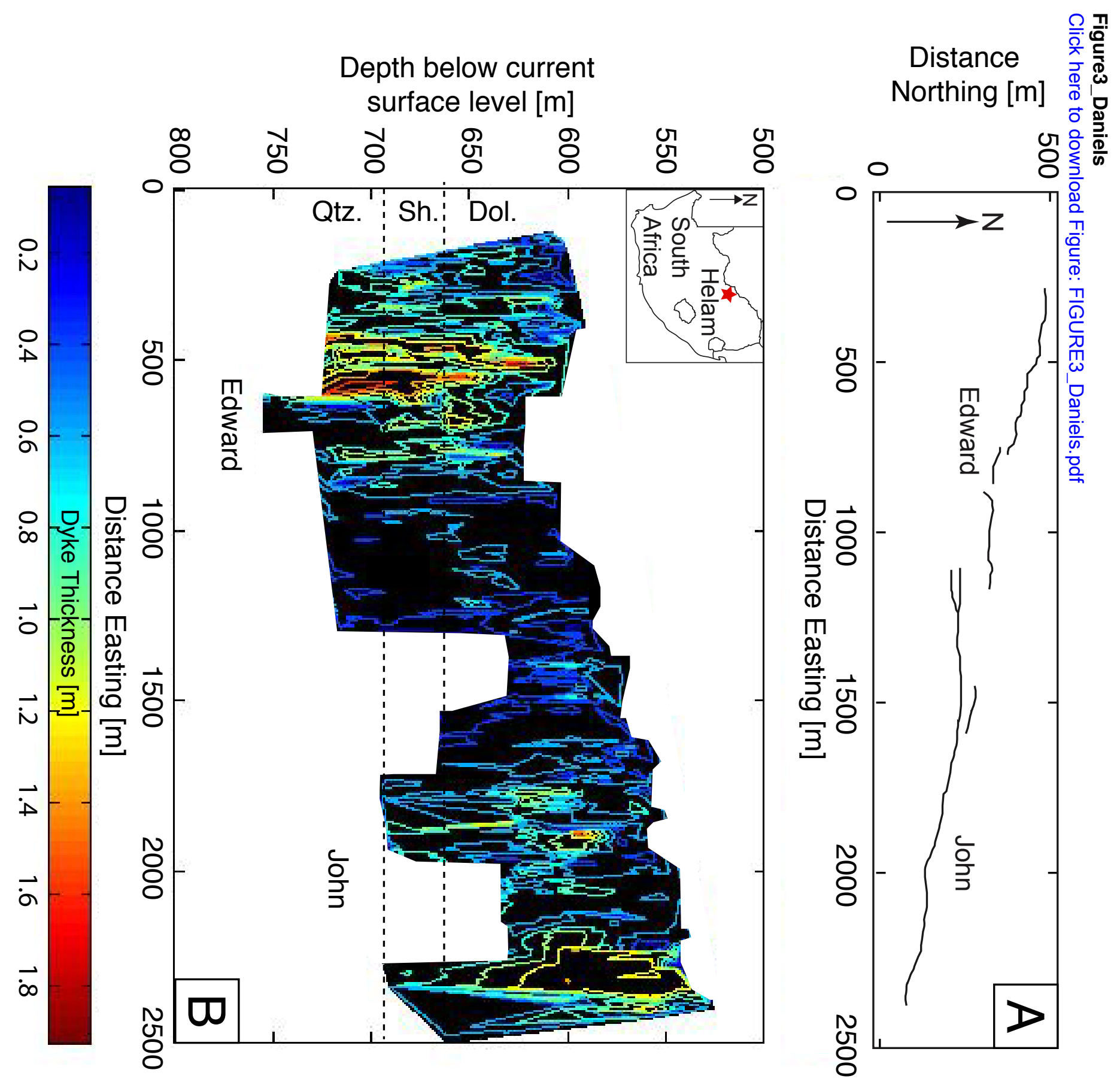




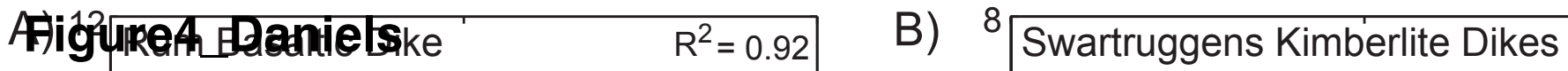

Cligknere to download Figure: FIGURE4_Däniels5. pdf
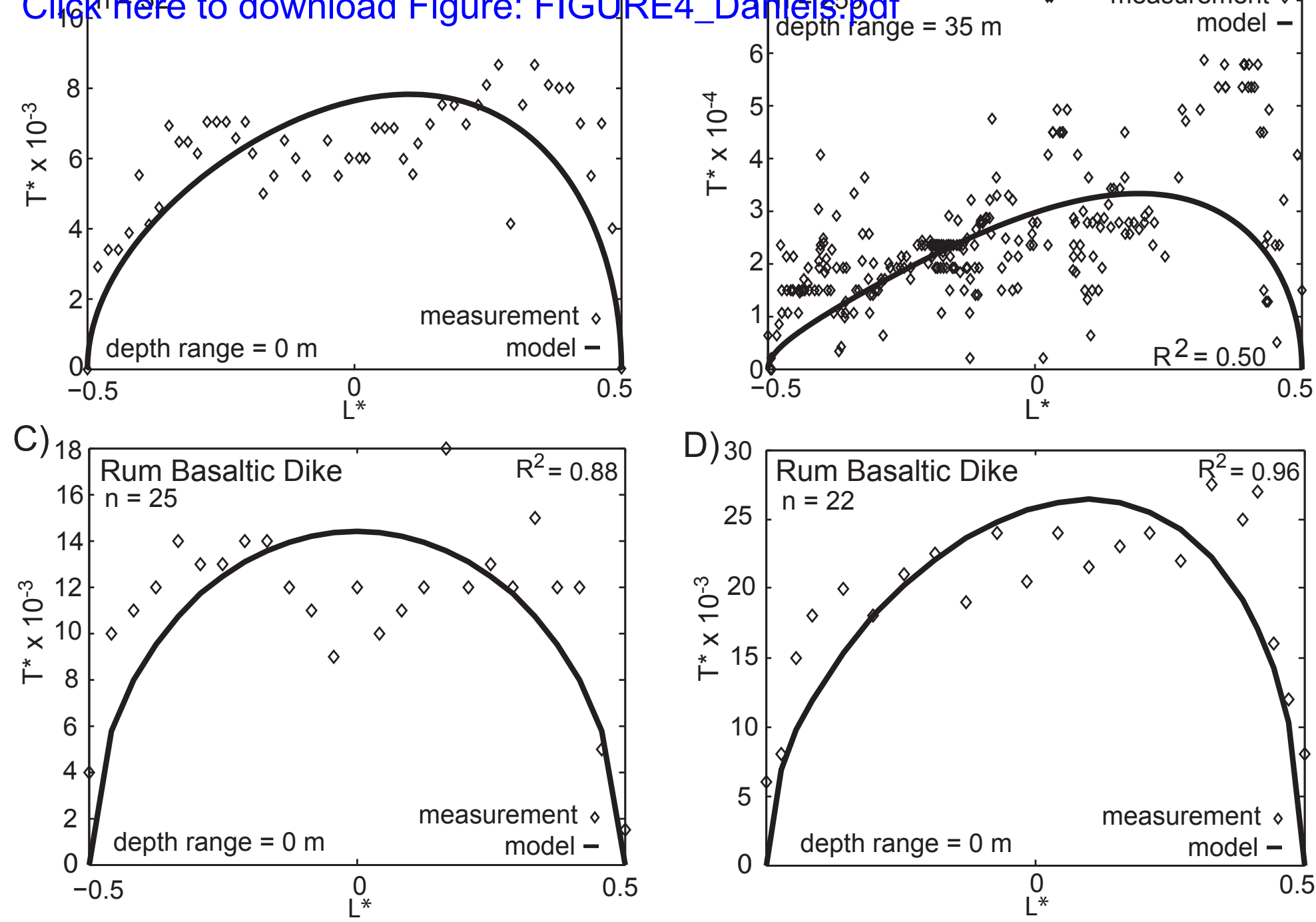
Figure5_Daniels

Cliek here to downtoadfigute.Figuref Dan Bells. pdf
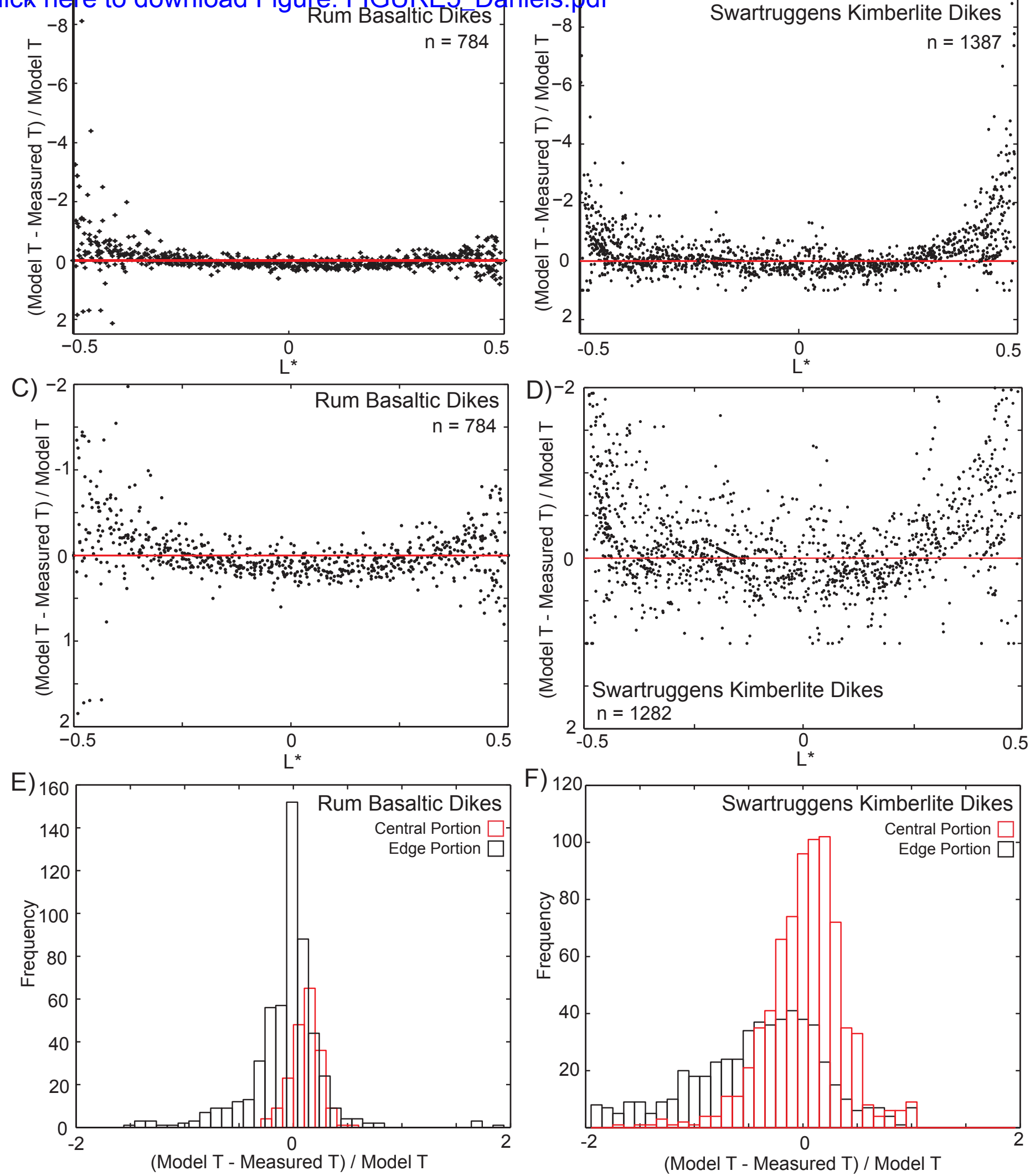

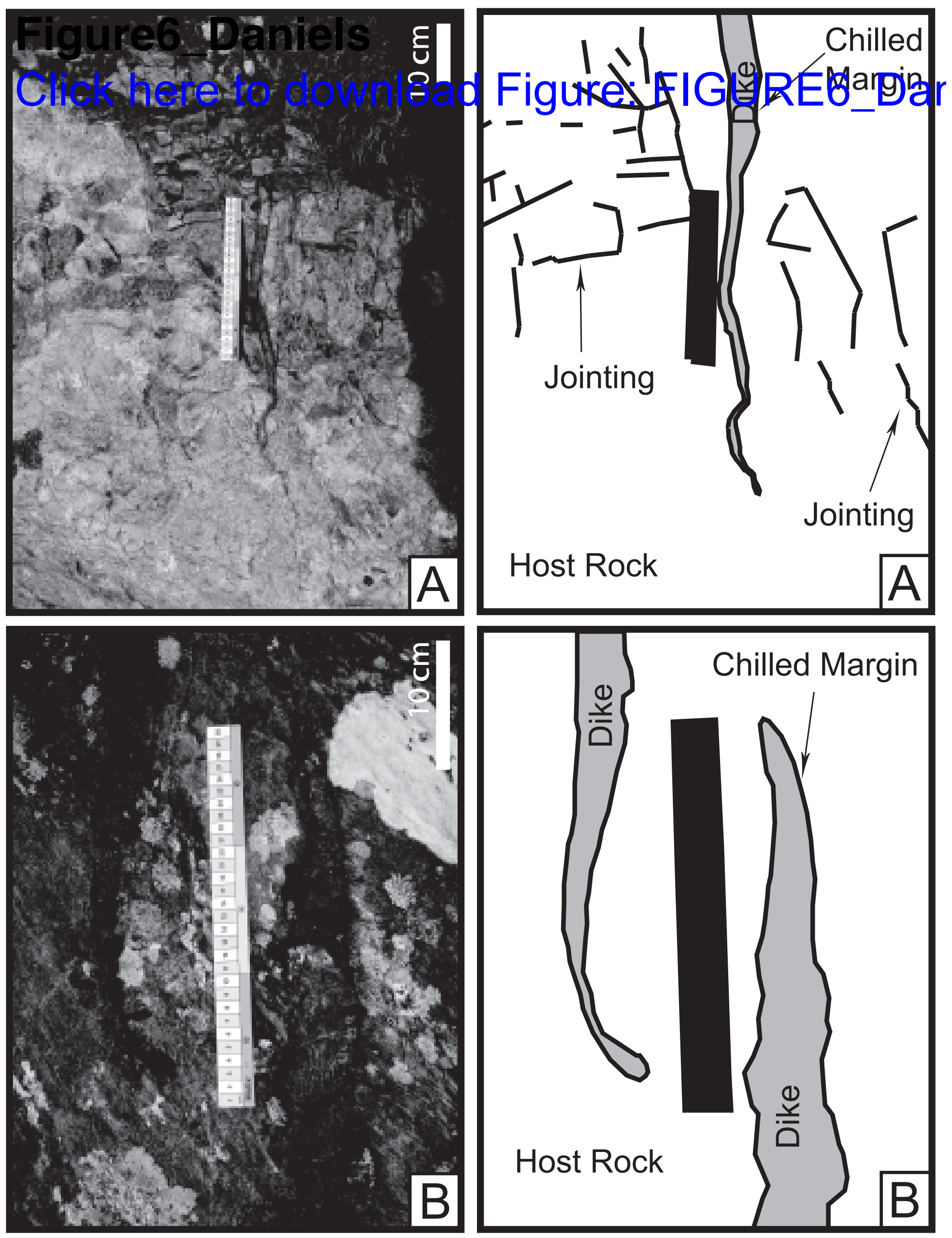

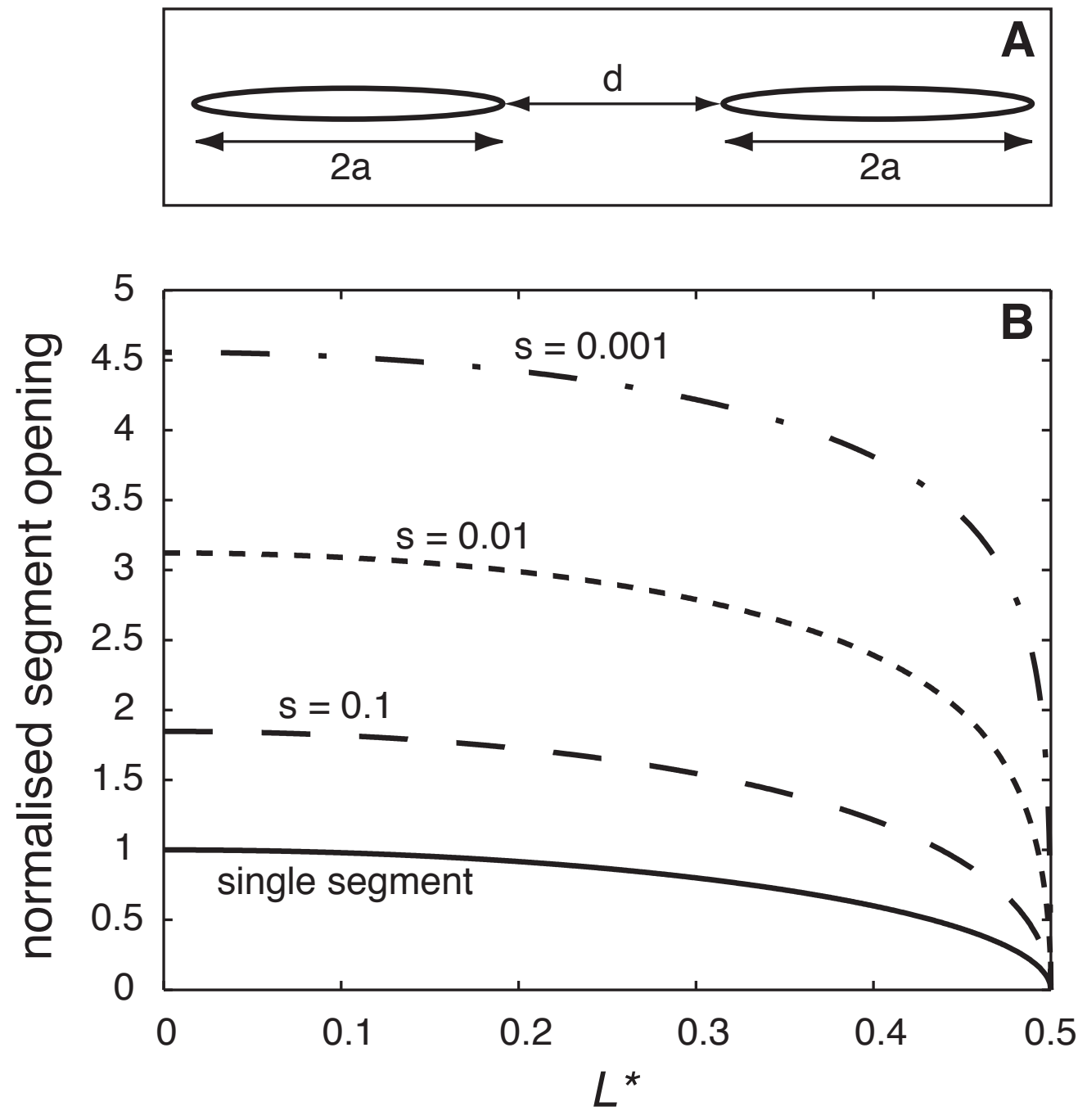
Figure8_Daniels

Click here to download Figure: FIGURE8_Daniels.pdf
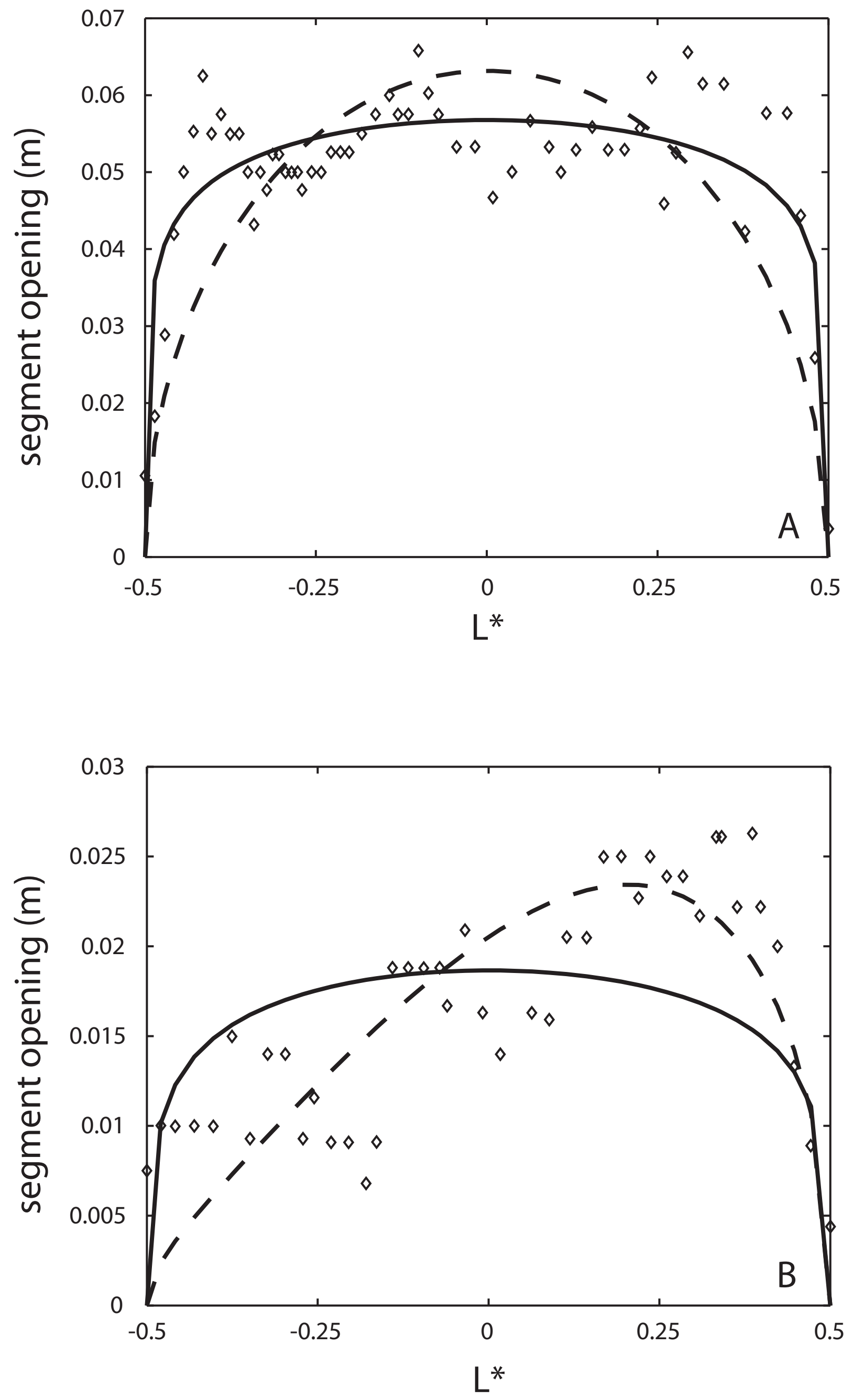


\section{Figuke Ba-Dlaniedsre}

Click hore to download Figutre: B) Chilled crack tips

C) Solidified magma in fracture 